\title{
Analyzing the Effect of Board of Commissioners' Characteristics, Managerial Ownership, and Financial Performance on Financial Risk Disclosure
}

\author{
Muhammad Syafwan Hady* \\ Faculty of Economics and Business, Universitas Sebelas Maret
}

\begin{abstract}
This study aims to examine the role of the board of commissioners' characteristics, managerial ownership, and financial performance on financial risk disclosure. The target population of this study was sharia banks registered in the Indonesian banking directory in 2012-2016. This study used secondary data in the form of annual financial statements obtained from the source sites of each bank. Using purposive sampling, 11 sharia banks in Indonesia were selected as the appropriate sample. This study employed a scoring technique to measure the level of financial risk disclosure. The results show that the independent variables including the board of commissioners size, independent board of commissioners proportion, profitability, and size as the control variable significantly influenced the variable of FRD. However, the variable of CAR, FDR, and managerial ownership had no effect on financial risk disclosure. The result of $\mathrm{F}$ test showed that independent variables included in the regression model simultaneously affected the dependent variable.
\end{abstract}

Keywords: board of commissioners characteristics, managerial ownership, financial performance, and financial risk disclosure

\section{Introduction}

Disclosure (disclosure) is expected to reduce the occurrence of information asymmetry (information asymmetry) between the management and the owner company (shareholders). The information asymmetry condition that manager (agent) has more information about company condition compared to a shareholder (principal). Jensen and Meckling (1976) emphasize that the importance of the company owner (principal) submit the management of the company to professionals (agents) who understand how to operate a business. This condition results in information asymmetry between the manager (agent) and shareholder (principal). Collier and Gregory (1999) argue that the size of a large board of commissioners will have significant strength in terms of pressuring management to disclose information about the company including financial risk disclosure. The results of the study from Suhardjanto (2011), suggest that the more the number of boards of commissioners, the supervision and pressure to management becomes stronger, thus encouraging more transparent management in terms of disclosing risks. The existence of an independent commissioner is influenced by management, which will encourage companies to make better disclosure of information, including disclosure of financial risks. This is in accordance with research conducted by Rahman and Banna (2016) on banking in India.

\footnotetext{
*Email: syafwan23@gmail.com
} 
The results of this study indicate that the composition of independent commissioners has a significant positive effect on the level of disclosure.

As a communication media, board of commissioners meetings can be used as a means of coordination among members of the board of commissioners as management supervisors. The number of meetings held by the board of commissioners will improve company performance and disclosure (Vafeas, 2003). The board of commissioners meeting is one of the intensive spaces to direct, monitor and evaluate the implementation of the bank's strategic policy pursuant to article 9, PBI Number: 8/14/PBI/2006. With regular and weighty meetings, the board of commissioners' meetings is able to give positive things to the company, including in terms of increasing the Financial Risk Disclosure. It is interesting to associate managerial ownership with agency theory. Agency theory states the relationship between managers and shareholders is described as the relationship between agents and principals (Dole et al., 2006). In the financial statements, managerial ownership is indicated by how much the percentage of ownership of shares owned by the company's manager. Because this is important information for the company's stakeholders, this information on managerial ownership will be disclosed in the financial statements.

Eng and Mak (2003) conducted research on the effect of the ownership structure proxied by managerial ownership and government ownership and board composition proxied with independent directors on voluntary disclosure. This study sampled 158 companies in Singapore in 1995. The result of this research is that there is a positive influence between managerial ownership on voluntary disclosure. This research is important because the focus of research is on Syariah banking where the bank is a highly regulated financial company. In addition, research on corporate governance in this study is projected by managerial ownership variables, commissioner characteristic consisting of board size, proportion of independent board of commissioner, and number of board meeting and profitability, liquidity, and capital adequacy ratio (CAR) which affects the practice of Financial Risk Disclosure of sharia banks in Indonesia is still rare. Based on the description, the title of this research is "Characteristics of Board of Commissioners, Managerial Ownership, and Financial Performance on Financial Risk Disclosure (Empirical Study at Sharia Commercial Bank in Indonesia Year 2012-2016)".

\section{Literature Review and Hypothesis Development}

Stakeholders will pay more attention to companies with larger sizes. The company will consider that way to enhance the company's reputation through risk disclosure. According to Dalton et al., (1999), the size of the maximum and efficient boards of directors will be more effective than small ones. Research Suhardjanto (2011) revealed that the size of the board of commissioners has a positive effect on the level of risk disclosure.

H1: The size of the board of commissioners has a positive effect on financial risk disclosure.

The culmination of the company's internal management system is the board of commissioners, which has a role in supervisory activities (Siallagan, 2006). Abeysekera (2010) states that the existence of an independent commissioner will enhance a reputation relating to more effective and efficient controls so as to have a significant effect on the level of corporate information disclosure. The results of this study are in line with research conducted by Abraham and Cox (2007).

$\mathrm{H} 2$ : The proportion of independent commissioners has a positive effect on financial risk disclosure.

The Board of Commissioners shall convene meetings at least four times a year, in accordance with Bank Indonesia Regulation Number 8/14 / PBI / 2006. The more frequent meetings held by the board of commissioners will further improve the performance of the company (Vafeas, 2003). In line with Vafeas (2003) research, Ettredge et al., (2010) suggest that the more board of commissioners' meetings encourage corporate compliance with mandatory disclosure.

H3: The number of board of commissioners meeting positively affects the financial risk disclosure. 
Managerial ownership is a condition in which ownership of shares by management, directors, commissioners or any parties directly involved in decision-making in a company. Patel and Dallas (2005) stated that there is a significant positive relationship of managerial ownership with the disclosure of financial statements. These results indicate that managerial ownership increases then the disclosure of financial statements more complete. Similarly, research conducted Barako (2007), in his research found a positive relationship between managerial ownership with the level of disclosure.

H4: Managerial ownership positively affects financial risk disclosure.

Measuring the efficiency of the company's activity and the company's ability to gain profit then use the level of profitability. To measure the company's profitability, current research uses ROA and ROE. The greater the profitability will be more extensive in the disclosure of financial statements, especially related to the disclosure of financial risks. Conversely, the smaller the profitability will be narrower in the disclosure of financial statements.

H5: Profitability ratio has a positive effect on financial risk disclosure.

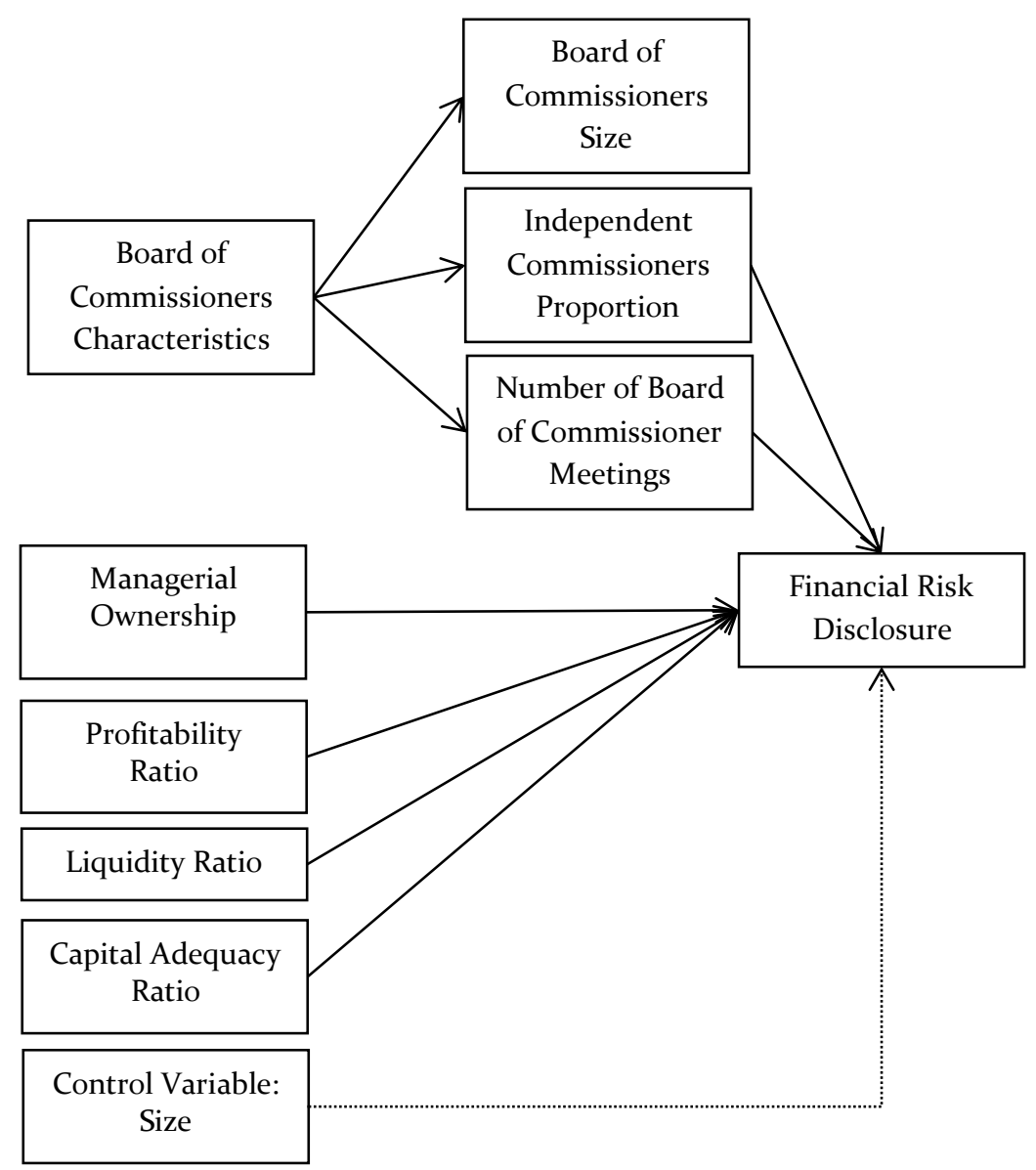

Figure 1. Research Framework

To measure the ability of banks to meet their financial obligations that must be met or short-term liabilities then use the ratio of liquidity. This ratio includes what investors often see before deciding to invest. Cooke (1989) explains that a high level of liquidity will indicate a strong financial condition. Such companies tend to disclose broader information to outsiders because they want to show that the company is credible. The results of research from Elzahar and Hussainey (2012) states that the liquidity ratio has a positive and significant influence with the disclosure of financial statements. 
H6: Liquidity ratio has a positive effect on financial risk disclosure.

To show the ability of banks in providing funds for business development purposes and accommodate the possibility of risk of losses caused in bank operations then use Capital Adequacy Ratio. The greater the ratio the better the capital position (Achmad, 2003). Capital Adequacy Ratio (CAR) studied by De Bondt, Gabe J., (2000) that the Capital Adequacy Ratio or the bank's capital adequacy ratio is positively associated with loan risk. In accordance with the previous hypothesis (H5), profitability ratio has a positive effect on the level of financial risk disclosure. So the development of the hypothesis is done

H7: Capital Adequacy Ratio (CAR) has a positive effect on financial risk disclosure level.

\section{Research Methods}

This research is a hypothesis testing that aims to test the hypothesis proposed by the researcher about financial risk disclosure in sharia bank that is influenced by managerial ownership, the characteristics of board of commissioner represented by the size of board of commissioner, number of board of commissioner meeting, composition of independent board of commissioner and ratio profitability, liquidity ratio, and CAR. According to Sekaran (2006), hypothesis testing should be able to explain the nature of a certain relationship, understand the differences between groups or the independence of two or more variables.

Referring to the Oorschot (2009) study, the quantity of financial risk disclosure can be determined by summing the disclosure score for each particular bank annual report in a given year, then dividing it by the maximum score that a particular bank can make in a given year.

Data analysis in this research was done by descriptive statistic, classical assumption test (normality test, multicollinearity test, autocorrelation test, and heteroscedasticity test) and hypothesis testing. Testing is done by using SPSS 20.0 program.

\section{Result and Discussion}

The sample in this study was selected using purposive sampling.

Table 4.1. Sample

\begin{tabular}{lc}
\hline Name & Annual Report \\
\hline Bank BCA Syariah & $2012-2016$ \\
Bank BJB Syariah & $2012-2016$ \\
Bank BRI Syariah & $2012-2016$ \\
Bank Bukopin Syariah & $2012-2016$ \\
Bank MEGA Syariah & $2012-2016$ \\
Bank Muamalat & $2012-2016$ \\
Bank Victoria Syariah & $2012-2016$ \\
Bank Panin Syariah & $2012-2016$ \\
Bank Mandiri Syariah & $2012-2016$ \\
Bank Maybank Syariah & $2012-2016$ \\
Bank BNI Syariah & $2012-2016$ \\
\hline
\end{tabular}


Descriptive statistics is an analysis used to provide an overview or description of a data viewed from the mean, maximum, minimum, sum, range, and standard deviation (Ghozali, 2006).

Table 4.2 Descriptive statistics

\begin{tabular}{lllllll}
\hline & $\mathrm{N}$ & Minimum & Maximum & Sum & Mean & Std. Deviation \\
\hline ROA & 55 & -2.36 & 20.13 & 78.35 & 1.4245 & 3.06903 \\
ROE & 55 & -49.05 & 57.98 & 350.80 & 6.3782 & 13.88475 \\
CAR & 55 & 11.10 & 63.89 & 1187.84 & 21.5971 & 12.12539 \\
FDR & 55 & 46.08 & 197.70 & 5314.16 & 96.6211 & 21.24498 \\
UDK & 55 & 2 & 6 & 213 & 3.87 & 1.123 \\
PDKI & 55 & 0.50 & 1.00 & 36.82 & 0.6694 & 0.13735 \\
JRPT & 55 & 3 & 36 & 704 & 12.80 & 7.516 \\
KM & 55 & 0.00 & 1.64 & 5.51 & 0.1001 & 0.32808 \\
FRD & 55 & 0.00 & 0.83 & 18.40 & 0.3345 & 0.19432 \\
\hline
\end{tabular}

Table 4.2 shows the average value of ROA (1.4245) with a maximum value of 20.13 by Maybank sharia bank and the minimum value of -2.36 by Victoria sharia bank. The ROE variable has an average value of 6.3782 with the maximum value of 57.98 by Mega sharia bank and the minimum value of 49.05 by BPJB sharia bank. The average of CAR (Capital Adequacy Ratio) is 21.5971 with the maximum value of 63.89 by Maybank sharia bank and the minimum value of 11.10 by Bukopin sharia bank. The average FDR (Financing to Deposit Ratio) is 96.6211 with the maximum value of 197.70 by Maybank sharia bank and the minimum value of 46.08 by Victoria sharia bank. The average size of the board of commissioners is 3.87 with the maximum number of 6 persons by Muamalat bank and BRI sharia bank and the minimum number of 2 persons by Maybank sharia bank. Abeysekera (2008) suggest that the number of effective commissioners is in the range of more than 5 persons and less than 14 persons. The average proportion of the dean of independent commissioners is 0.6694 with the maximum amount of 1.00 by Mega sharia bank and Maybank sharia bank and the minimum amount 0.50 by Muamalat bank, BJB sharia bank, Bukopin sharia bank, and BNI sharia bank. Therefore, the average amount of proportion of independent commissioners in a bank is $66.94 \%$ of the total number of boards of commissioners.

The average number of board meetings was 12.80 or 13 times a year. With the maximum amount of 36 meetings by BRI sharia bank and the minimum amount of 3 meetings by Muamalat bank. The board of commissioners shall convene regular meetings at least four times a year (PBI Number: $8 / 14 / \mathrm{PBI} / 2006)$. The average of managerial ownership was $0.10 \%$. With the maximum amount of $1.64 \%$ by Bukopin sharia bank and the minimum amount of $0.0 \%$ by the majority of other sharia banks. The dependent variable in this research was financial risk disclosure. The average of financial risk disclosure was 0.3345 or $33.45 \%$ with the maximum value of 0.83 by Panin sharia bank and the minimum value of 0.00 by Victoria sharia bank in 2012. The results indicated that the level of risk disclosure by sharia banks in Indonesia still needed to be improved considering financial risk disclosure is one of the compulsory disclosures in accordance with PSAK No.31 (revised in 2000), PBI Number: 5/8/PBI/2003, and PSAK No. 50 (revised in 2006).

\section{Classical Assumption Testing \\ Normality Testing}

Normality Test Objective is to see whether the data used is normally distributed or not. Normality test also aims to test whether the model in the regression, residual variable or bullies have a normal distribution (Ghozali, 2006). Normality test is done by testing the residual normality ie by statistical test non-parametrik Kolmogorov-Smirnov (k-s). The result shows the value of Asymp. Sig. (2-tailed) (0.958) more than 0.05 . Therefore, it can be concluded the data has been distributed normally. 
Table 4.3. Normality Testing Results One-Sample Kolmogorov-Smirnov Testing

\begin{tabular}{lll}
\hline & & $\begin{array}{l}\text { Unstandardized } \\
\text { Residual }\end{array}$ \\
\hline $\mathrm{N}$ & & 55 \\
Normal Parameters & Mean & 0.0000000 \\
& Std. Deviation & 0.12781118 \\
Most Extreme & Absolute & 0.069 \\
Differences & Positive & 0.061 \\
& Negative & -0.069 \\
Kolmogorov-Smirnov Z & & 0.509 \\
Asymp. Sig. (2-tailed) & & 0.958 \\
\hline
\end{tabular}

\section{Multicollinearity Testing}

The multicollinearity test aims to test whether there is a high correlation between two or more independent variables in which this problem often appears in regression analysis (Ghozali, 2006).

Table 4.4. Multicollinearity Testing Result

\begin{tabular}{llll}
\hline Variable & Tolerance & VIF & Result \\
\hline ROA & .487 & 2.053 & Non multicollinearity \\
ROE & .552 & 1.812 & Non multicollinearity \\
CAR & .221 & 4.519 & Non multicollinearity \\
FDR & .382 & 2.616 & Non multicollinearity \\
UDK & .298 & 3.360 & Non multicollinearity \\
PKI & .674 & 1.483 & Non multicollinearity \\
JRPT & .846 & 1.182 & Non multicollinearity \\
KM & .742 & 1.347 & Non multicollinearity \\
SIZE & .305 & 3.281 & Non multicollinearity \\
\hline
\end{tabular}

The table above shows the output value of SPSS 20.0 that all independent variables have the VIF value $<10$ and no independent variable has a tolerance value less than 0.1 . This means that the above data is free from multicollinearity.

\section{Autocorrelation Testing}

Autocorrelation testing aims to test whether in the linear regression model there is a correlation between the nuisance error in period $t$ with the nuisance error in period $t-1$ or the previous period (Ghozali, 2006). This research used the Runs test tool. In the Run test, autocorrelation can be indicated from the table. Table 4.5 shows that the regression model used in this study is free from symptoms of autocorrelation as the significant value is greater than $0.05(0.342)$.

Table 4.5. Autocorrelation Testing Result Runs Test

\begin{tabular}{lr}
\hline & Unstandardized \\
& Residual \\
\hline Test Value & -0.01056 \\
Cases < Test Value & 27 \\
Cases >= Test Value & 28 \\
Total Cases & 55 \\
Number of Runs & 25 \\
Z & -.951 \\
Asymp. Sig. (2-tailed) & 0.342 \\
\hline
\end{tabular}




\section{Heteroscedasticity Testing}

Heteroscedasticity testing test aims to test whether in the regression model there is a variance inequality in several residual observation (Ghozali, 2006). This research used Rank Spearman method to test heteroscedasticity. Assuming that if the value of Sig. (2-tailed) greater than 0.05 it is concluded that there is no problem of heteroscedasticity.

\begin{tabular}{llc}
\multicolumn{3}{l}{ Table 4.6. Heteroscedasticity Testing Result } \\
\hline Method & Variable & $\begin{array}{c}\text { Value of } \\
\text { Sig. (2-tailed) }\end{array}$ \\
\hline Spearman's rho & ROA & 0.283 \\
& ROE & 0.378 \\
& CAR & 0.783 \\
& FDR & 0.738 \\
& UDK & 0.461 \\
& PKI & 0.813 \\
& JRPT & 0.520 \\
& KM & 0.994 \\
& SIZE & 0.639
\end{tabular}

Table 4.6 shows that the value of independent variables with unstandardized residual has the significance value of more than 0.05 . Therefore, there was no problem of heteroscedasticity in the regression model.

\section{Hypothesis Testing}

Simultaneous Hypothesis Testing ( F test)

$\mathrm{F}$ test aims to determine whether all independent variables included in the regression model have a simultaneous effect on the dependent variable. The f statistic test is performed with 5\% (significant) degree of trust. The result of $\mathrm{f}$ test is presented in the table below.

Table 4.7. F Test Result

\begin{tabular}{|c|c|c|c|c|c|c|}
\hline Model & & $\begin{array}{l}\text { Sum of } \\
\text { Squares }\end{array}$ & $\mathrm{df}$ & Mean Square & $\mathrm{F}$ & Sig. \\
\hline & Regression & 1.157 & 9 & 0.129 & 6.557 & $0.000^{\mathrm{a}}$ \\
\hline & Residual & 0.882 & 45 & 0.020 & & \\
\hline & Total & 2.039 & 54 & & & \\
\hline
\end{tabular}

Table 4.7 above shows that the value of calculated $\mathrm{F}$ is 6.557 and $\mathrm{F}$ table at $5 \%$ error rate is 2.10 (calculated $\mathrm{F}>\mathrm{F}$ table) and significance value is 0.000 at significance level $\alpha$ equal to 0.5 . This meant that the independent variables (ROA, ROE, CAR, FDR, UDK, PKI, JRPT, KM, and SIZE) included in the regression model had a mutual effect on the dependent variable (FRD).

\section{Partial Hypothesis Testing (t-test)}

The statistical t-test is used to indicate how great the influence of an explanatory or independent variable individually in explaining the variation of the dependent variable (Ghozali, 2006). To interpret the coefficients of independent variables unstandardized coefficients and standardized coefficients can be used (Ghozali, 2006). The result of $t$ test using of SPSS 20.0 program is presented in table 4.9 below. 
Table 4.8. T-Test Result

\begin{tabular}{ll}
\hline Model & Sig. \\
\hline (Constant) & 0.000 \\
ROA & 0.025 \\
ROE & 0.002 \\
CAR & 0.821 \\
FDR & 0.674 \\
UDK & 0.000 \\
PKI & 0.001 \\
JRPT & 0.515 \\
KM & 0.156 \\
SIZE & 0.000 \\
\hline
\end{tabular}

Table 4.8 shows that the significant level of the ROA was 0.025 , ROE was 0.002 , board size was 0.000 , and the proportion of independent board of commissioners was 0.001 , meaning that all values were smaller than 0.05 . This meant that ROA, ROE, board size, and proportion of independent board of commissioners had a significant effect on financial risk disclosure. While the significance level of CAR was 0.821 , FDR was 0.674 number of board meetings was 0.515 , and managerial ownership was 0.156 , meaning that all values were greater than 0.05 . This showed that CAR, FDR, number of the board meeting and managerial ownership variables had no significant effect on financial risk disclosure.

\section{Board of Commissioners Size has a significant effect on financial risk disclosure}

Based on the output of SPSS 20.0 it can be seen that the size of the board of commissioners has a significant value of 0.000 at the 0.050 level of significance. This shows that the size of the board of commissioners has a significant effect on financial risk disclosure. This means that the greater the number of members of the board of commissioners of a company will provide more optimal supervision of management so that the company will disclose financial risk with better, complete, and informative.

The results of this study are in line with research conducted by and Abeysekera, (2008) who found that the board of commissioners have a positive effect on the extent of disclosure made by the company. This result is in line with the first hypothesis in this study so that the first hypothesis is accepted.

The proportion of independent commissioners significantly influences financial risk disclosure

Based on the output of SPSS 20.0 it can be seen that the proportion of independent commissioners has a significant value of 0.001 at the 0.050 level of significance. This shows that the proportion of independent commissioners has a significant effect on financial risk disclosure.

This study is in line with research conducted by Abraham and Cox (2007) found that independent commissioners positively influence risk disclosure.

The number of board of commissioners meeting has a positive effect on financial risk disclosure

Based on the output of SPSS 20.0 it can be seen that the number of board of commissioners meeting has a significant value of 0.515 at the 0.050 level of significance. This shows that the number of board of commissioners meeting has no significant effect on financial risk disclosure. The results of this study are in line with the research conducted by Brick and Chidambaran (2010) where the corporate risk disclosures contained in the annual report are operational policies of management and discussed by the management and the ranks below, so as not to be the main agenda of discussion in the board of commissioners meeting. So that the number of board of commissioners in a year does not significantly affect the company's risk disclosure. 


\section{Managerial ownership positively affects financial risk disclosure}

Based on the output of SPSS 20.0 it can be seen that managerial ownership has a significant value of 0.156 at the 0.050 level of significance. This shows that managerial ownership has no significant effect on financial risk disclosure. Consistent with past study results that note the negative relationship between managerial ownership and disclosure level (David, 2000; Eng and Mak, 2003), whereas in the study of Probohudono et al. (2013) examines that there is consistently no effect of managerial ownership on risk disclosure.

\section{Profitability ratio has a significant effect on financial risk disclosure}

Based on the results of SPSS 20.0 output can be seen that ROA and ROE each has a significant value of 0.025 and 0.000 at the level of significance of 0.050 . This shows that profitability using ROA and ROE have a significant effect on financial risk disclosure. This result is also in accordance with the results of research conducted by Hossain (2008) which states that the variable profitability of the company has an influence on the level of risk disclosure (risk disclosure).

\section{Liquidity ratio has a significant effect on financial risk disclosure}

Based on the output of SPSS 20.0 it can be seen that the FDR has a significant value of 0.674 at a significance level of 0.050 . This shows that liquidity using FDR has no significant effect on financial risk disclosure. The research conducted by Fitriani (2001) found that the level of liquidity does not affect the completeness of corporate disclosure. This is in line with research conducted by Elzahar and Hussainey (2012) where the level of liquidity has no significant effect on risk disclosure.

\section{Capital Adequacy Ratio (CAR) has a significant effect on the level of financial risk disclosure}

Based on the output of SPSS 20.0 can be seen that the CAR has a significant value of 0.821 at the level of significance of 0.050 . This shows that CAR has no significant effect on financial risk disclosure. But this study is in line with that done by Rahman and Banna (2016) showed that CAR has a negative influence on liquidity risk in conventional banks and sharia banks

Size as a control variable has a significant value of 0.000 at the 0.050 significance level. This shows that size has a significant effect on financial risk disclosure. Company size affects the level of financial risk disclosure. Large companies will be a concern for stakeholders to know how the company's condition. In addition to being a concern for stakeholders, the company tends to have many shareholders. Based on agency theory, the larger the size of the company, the agency costs will also be greater. Disclosure of information is a feasible way to reduce agency costs.

This is in line with the research of Linsley and Shrives (2006) and Amran et al., (2009). Large firms have more complex business activities that may have a greater impact on companies and stakeholders, better manage and assume critical risk disclosures for companies, thus disclosing more information to demonstrate corporate accountability to the public. In addition, the larger the size of the company means the increasing number of stakeholders involved.

\section{Conclusion}

The result of t-test shows the profitability represented by ROA and ROE, UDK, PKI and size as the control variable of each variable significantly affecting the financial risk disclosure variable. While the variable of JRPT, Capital Adequacy Ratio, Financing to Deposit Ratio, and Managerial Ownership have no effect on financial risk disclosure variable. However, the result of $\mathrm{f}$ test shows that the independent variables (ROA, ROE, CAR, FDR, UDK, PKI, JRPT, KM, and SIZE) included in the regression model affect the dependent variable (FRD).

There are several suggestions based on the conclusion of the research (1) for management, the results of this study can be used as a reference to perform remedial actions on financial risk disclosure, (2) for investors, this study result can be used as a reference to make a right decision in investing in a company, (3) for further researchers, this study can be used as a comparison to investigate the level of financial risk disclosure between industries in Indonesia and other countries (comparative study). 


\section{References}

Abeysekera, I. (2010), "The influence of board size on intellectual capital disclosure by Kenyan listed firms", Journal of Intellectual Capital, Vol. 11 No. 4, pp. 504-518.

Abraham, S. and Cox, P. (2007), "Analysing the determinants of narrative risk information in UK FTSE 100 annual reports”, British Accounting Review, Vol. 39 No. 3, pp. 227-248.

Achmad, T.K. (2003), Analisis Rasio-Rasio Keuangan Sebagai Indikator Dalam Memprediksi Potensi Kebangkrutan Perbankan Indonesia.

Amran, A., Manaf Rosli Bin, A. and Che Haat Mohd Hassan, B. (2009), "Risk reporting: An exploratory study on risk management disclosure in Malaysian annual reports”, Managerial Auditing Journal, Vol. 24 No. 1, pp. 39-57.

Barako, D.G. (2007), "Determinants of Voluntary Disclosures in Kenyan Companies Annual Reports", African Journal of Business Management, Vol. 1, pp. 113-128.

De Bondt, Gabe J., and H.M.P. (2000), Bank Capital Ratios in the 1990s: Cross-Country Evidence, Vol. 65, De Nederlandsche Bank.

Brick, I.E. and Chidambaran, N.K. (2010), "Board meetings, committee structure, and firm value”, Journal of Corporate Finance, Elsevier B.V., Vol. 16 No. 4, pp. 533-553.

Collier, P. and Gregory, A. (1999), "Audit committee activity and agency costs", Journal of Accounting and Public Policy, Vol. 18 No. 4-5, pp. 311-332.

Cooke, T.E. (1989), "Disclosure in the Corporate Annual Reports of Swedish Companies", Accounting and Business Research, Vol. 19 No. 74, pp. 113-124.

Dalton, D.R., Daily, C.M., Johnson, J.L. and Ellstrand, A.E. (1999), "Number of directors and financial performance: A meta-analysis", Academy of Management Journal, Vol. 42 No. 6, pp. 674-686.

David, S.G. (2000), "Managerial Ownership and Accounting Disclosures: An Empirical Study", Review of Quantitative Finance and Accounting, Vol. 15 No. 2, available at: http://www.springerlink.com/content/loh55032r178uo21/.

Dole, C., Schroeder, R.G., Reed, S.A., Kratchman, S.H., Strawser, R.H., Satisfaction, J., Commitment, O., et al. (2006), "accountants Users who downloaded this article also downloaded: The impact of various factors on the personality, job satisfaction and turnover intentions of professional accountants".

Elzahar, H. and Hussainey, K. (2012), "Determinants of narrative risk disclosures in UK interim reports”, Journal of Risk Finance, Vol. 13 No. 2, pp. 133-147.

Eng, L.L. and Mak, Y.T. (2003), "Corporate governance and voluntary disclosure”, Journal of Accounting and Public Policy, Vol. 22 No. 4, pp. 325-345.

Ettredge, M. L., Scholaz, S., Smith, K., And Sun, L. (2010), "How Do Misstatement Begin? Evidence Of Beiased Finance Reporting Preceding Misstatements", Journal Of Business Finance And Accounting, Vol. 37 No. 332-355.

Fitriani, F. (2001), Signifikansi Perbedaan Tingkat Kelengkapan Pengungkapan Wajib Dan Sukarela Pada Laporan Keuangan Perusahaan Publik yang Terdaftar di Bursa Efek Jakarta, Simposium Nasiona Akuntansi IV, Bandung.

Ghozali, I. (2006), Aplikasi Analisis Multivariate Dengan Program SPSS, 4th ed.

Hossain, M. (2008), "The Extent of Disclosure in Annual Reports of Banking Companies: The Case of India”, European Journal of Scientific Research, Vol. 23, pp. 660-681.

Jensen, M. and Meckling, W. (1976), “Theory of the firm: Managerial behavior, agency costs and ownership”, Strategic Management Journal, Vol. 21 No. 4, pp. 1215-1224.

Linsley, P.M. and Shrives, P.J. (2006), "Risk reporting: A study of risk disclosures in the annual reports of UK companies”, British Accounting Review, Vol. 38 No. 4, pp. 387-404.

Oorschot, L. Van. (2009), Risk Reporting: An Analysis Of The German Banking Industry. Erasmus University Rotterdam, School Of Economics, Master Accounting, Auditing, and Control.

Patel, S.A. and Dallas, G.S. (2005), "Transparency and Disclosure: Overview of Methodology and Study Results - the United States", SSRN Electronic Journal, available at:https://doi.org/10.2139/ssrn.4228oo.

Probohudono, A.N., Tower, G. and Rusmin, R. (2013), "Risk disclosure during the global financial crisis", Social Responsibility Journal, Vol. 9 No. 1, pp. 124-136.

Rahman, M.L. and Banna, S.H. (2016), "Liquidity Risk Management: A Comparative Study between Conventional and Islamic Banks in Bangladesh”, Journal of Business and Technology (Dhaka), Vol. 10 No. 2, pp. 18-35.

Sekaran, U. (2006), Research Methods for Business, Salemba Empat, Jakarta.

Siallagan, H. (2006), Mekanisme Corporate Governance, Kualitas Laba Dan Nilai Perusahaan, Artikel Simposium Nasional Akuntansi (SNA) IX, Padang.

Suhardjanto, D. (2011), "Pengungkapan Risiko Finansial dan Tata Kelola Perusahaan: Studi Empiris Perbankan Indonesia”, Jurnal Keuangan Dan Perbankan, Vol. 15, pp. 105-108. 